\section{Foliar Applications of Plant Growth Regulators Affect Stem Elongation and Branching of 11 Kalanchoe Species}

\author{
Christopher J. Currey and John E. Erwin ${ }^{1,2}$
}

ADDITIONAL INDEX WORDS. ancymidol, benzyladenine, chlormequat chloride, ethephon, paclobutrazol, uniconazole

SUMMARY. Our objectives were to assess the efficacy of various plant growth regulators (PGRs) on stem elongation and branching of 11 kalanchoe (Kalanchoe) species with ornamental characteristics: beauvard's widow's-thrill ( $K$. beauvardii), $K$. glaucescens, lavender scallops or red-leaved kalanchoe (K. fedtschenkoi), $K$. longiflora, chandelier plant (K. manginii), marnier's kalanchoe (K. marnieriana), $K$. millotii, flower dust plant (K. pumila), K. rosei, common kalanchoe or nentabos (K. rotundifolia), and K. streptantha. Foliar spray applications of deionized water, ancymidol (15-60 ppm), benzyladenine (75-300 ppm), chlormequat chloride (750-3000 ppm), daminozide (1250-5000 ppm), ethephon $(250-1000 \mathrm{ppm})$, paclobutrazol $(10-40 \mathrm{ppm})$, or uniconazole $(5-20 \mathrm{ppm})$ were applied 2 weeks after plants were pinched. Stem length at the time of application and 4 weeks after applications and branch number were recorded. While effective chemicals and concentrations varied widely among species, paclobutrazol and uniconazole were identified as providing broad efficacy with respect to inhibition of stem elongation across all 11 species in this study. Additionally, benzyladenine and ethephon increased the number of branches for several species.

$\mathrm{I}$ $t$ is desirable for commercial potted, bedding, and foliage plants to be well-branched and compact in habit (Roh and Lawson, 1998). Ideally, these characteristics are achieved genetically through breeding and selection during crop development. However, when compact height and high branch number does not occur naturally, environmental or mechanical manipulation by reducing the difference in day and night air temperatures (DIF) or pinching, respectively, can be used to suppress height and increase branch number (Andersen and Andersen, 2000). Chemical suppression of stem elongation and increased branching is possible with the use of different types of PGRs. For example, applications of inhibitors of gibberellin synthesis or ethylene generators will suppress cell elongation and, thus, stem length (Rademacher, 2000). Additionally, exogenous applications of a cytokinin or ethylene generators can suppress apical dominance and release axillary

Department of Horticultural Science, University of Minnesota, 1970 Folwell Avenue, Saint Paul, MN 55108-6007

Mention of trade names in this publication does not imply endorsement by the Minnesota Agriculture Experiment Station of products named, nor criticisms of similar products not named.

${ }^{1}$ Professor

${ }^{2}$ Corresponding author. E-mail: erwin001@umn.edu. buds by lowering the ratio of auxin to cytokinin or ethylene, thereby enhancing branching (Srivastava, 2002).

PGRs are regularly applied in commercial ornamental plant production to improve the ornamental and aesthetic characteristics of plants, including stem length and branching (Gent and McAvoy, 2000). There are several methods used to apply PGR solutions, including: bulb, tuber, or rhizome soaks or dips (Currey and Lopez, 2010; Krug et al., 2005); liner dips (Blanchard and Runkle, 2007; Schnelle and Barrett, 2010); substrate drenches (Currey and Lopez, 2011; Sellmer et al., 2001); and foliar sprays (Gibson and Whipker, 2003; Whipker and Dasoju, 1998). Foliar sprays have the advantage of being a relatively easy application method, inexpensive to apply with respect to labor, often use less total chemical, and are appropriate for nearly every PGR. As such, foliar sprays are the most common method employed for PGR application (Gent and McAvoy, 2000).

Though spray application of most PGRs elicit an effective response, the efficacy of different chemicals and concentrations can vary among and within genera, species, and cultivars (Seely, 1979). For example, Warner and Erwin (2003) and Nordwig (1999) reported variation among several hibiscus ( $\mathrm{Hi}$ biscussp.) and milkweed species (Asclepias sp.), respectively, to different PGRs at varying concentrations when applied as sprays. Similarly, Boldt (2008), Gibson and Whipker (2001), and Krug et al. (2007) reported variation among cultivars of angelonia (Angelonia angustifolia), ornamental cabbage and kale (Brassica oleracea), and tulip (Tulipa gesneriana) in response to different PGRs.

There are 139 species of kalanchoe (Descoings, 2005). However, only florists' kalanchoe (Kalanchoe blossfeldiana) is widely grown as an ornamental plant (Dole and Wilkins, 2005). We identified numerous kalanchoe species with commercial ornamental crop potential based on unique flowering and/or vegetative characteristics (Currey, 2009; Currey and Erwin, 2010, 2011a, 2011b). While these species possess unique ornamental floral, foliar, and/or vegetative qualities, they are neither compact nor free-branching (Currey and Erwin, 201la). The use of chemical PGRs to inhibit stem elongation, enhance branching, or both may aide in adapting these species to ornamental flowering plant culture (Davis and Andersen, 1989).

Various PGRs effectively inhibit stem elongation of $K$. blossfeldiana and K. porphyrocalyx (Adriansen, 1989; Carlson et al., 1977; Cathey and Stuart, 1961; Hwang et al., 2008; Lee et al., 2003; Nightingale, 1970; Pertuit, 1973; Ueber, 1998; Zimmer, 1985) and increase or enhance branching for $K$. blossfeldiana and $K$. tomentosa (Lyons and Hale, 1987; Pertuit, 1973). There is little, or no, information on

\begin{tabular}{llll}
\hline $\begin{array}{l}\text { Units } \\
\begin{array}{l}\text { To convert U.S. to SI, } \\
\text { multiply by }\end{array}\end{array}$ & U.S. unit & SI unit & $\begin{array}{l}\text { To convert SI to U.S., } \\
\text { multiply by }\end{array}$ \\
\hline 29.5735 & $\mathrm{fl} \mathrm{oz}$ & $\mathrm{mL}$ & 0.0338 \\
2.54 & inch(es) & $\mathrm{cm}$ & 0.3937 \\
16.3871 & inch & $\mathrm{cm}^{3}$ & 0.0610 \\
1 & $\mathrm{ppm}$ & ${\mathrm{Mg} \cdot \mathrm{L}^{-1}}^{3}$ & 1 \\
0.1019 & $\mathrm{qt} / 100 \mathrm{ft}^{2}$ & $\mathrm{~L} \cdot \mathrm{m}^{-2}$ & 9.8170 \\
$\left({ }^{\circ} \mathrm{F}-32\right) \div 1.8$ & ${ }^{\circ} \mathrm{F}$ & ${ }^{\circ} \mathrm{C}$ & $\left(1.8 \times{ }^{\circ} \mathrm{C}\right)+32$
\end{tabular}


what PGRs are effective on the species previously identified with ornamental potential. Therefore, our objectives were to assess the efficacy of various PGRs on stem elongation and branching of several kalanchoe species with ornamental characteristics.

\section{Materials and methods}

Stock Plant culture. Vegetative stock plants of $K$. beawvardii, $K$. glaucescens, K. fedtschenkoi, K. longiflora, K. manginii, K. marnieriana, K. millotii, K. pumila, K. rosei, $K$. rotundifolia, and $K$. streptantha were maintained in a greenhouse with
$22 \pm 1{ }^{\circ} \mathrm{C}$ and $18 \pm 1{ }^{\circ} \mathrm{C}$ day and night air temperature set points, respectively, under ambient light conditions (St. Paul, $\mathrm{MN}$, lat. $45^{\circ} \mathrm{N}$ ) supplemented with $75 \mu \mathrm{mol} \cdot \mathrm{m}^{-2} \cdot \mathrm{s}^{-1}$ photosynthetic photon flux (PPF) from high-pressure sodium lamps when ambient light was $<200 \mu \mathrm{mol} \cdot \mathrm{m}^{-2} \cdot \mathrm{s}^{-1}$ from 0700 to $0100 \mathrm{HR}$ (18-h photoperiod). Plants were irrigated when the substrate appeared dry with tap water and fertilized once weekly with tap water supplemented with $15 \mathrm{~N}-2.2 \mathrm{P}-12.5 \mathrm{~K}$ watersoluble fertilizer (Excel Cal-Mag; Scotts, Marysville, $\mathrm{OH}$ ) to provide 200 ppm nitrogen.

Table 1. Average day and night air temperatures and daily light integral (DLI) in the greenhouse during the 4 weeks following application of foliar sprays containing deionized water, ancymidol, benzyladednine, chlormequat chloride, daminozide, ethephon, paclobutrazol, or uniconazole to 11 kalanchoe species.

\begin{tabular}{lccc}
\hline & \multicolumn{2}{c}{ Temp $\left[\text { mean } \pm \text { SD }\left({ }^{\circ} \mathbf{C}\right)\right]^{\mathrm{z}}$} & \\
\cline { 2 - 3 } Expt. & Day & Night & DLI $\left(\mathbf{m o l} \cdot \mathbf{m}^{-2} \cdot \mathbf{d}^{-1}\right)$ \\
\hline 1 & $22.3 \pm 2.0$ & $18.5 \pm 1.6$ & 9.6 \\
2 & $22.9 \pm 2.2$ & $18.6 \pm 1.9$ & 11.3 \\
3 & $23.7 \pm 3.7$ & $20.4 \pm 2.3$ & 16.0 \\
4 & $24.4 \pm 3.6$ & $20.9 \pm 2.4$ & 17.1 \\
\hline${ }^{2}\left(1.8 \times{ }^{\circ} \mathrm{C}\right)+32={ }^{\circ} \mathrm{F}$ & & &
\end{tabular}

Expт. 1. On 19 Dec. 2008 , terminal shoot-tip cuttings of $K$. marnieriana, K. rosei, and K. streptantha with about three to five nodes, depending on the species, were harvested from vegetative stock plants. The lowest set of leaves was removed from cuttings, and cuttings were dipped in talc powder containing $1000 \mathrm{ppm}$ indole-3-butyric acid (Hormodin 1; OHP, Mainland, $\mathrm{PA})$ to promote rooting. Cuttings were then placed in a soilless highporosity substrate composed of pine bark, canadian sphagnum peat, vermiculite, and coarse perlite (SB500; Sun Gro Horticulture, Bellevue, WA) in 128 -cell plug trays $(25-\mathrm{mL}$ individual cell volume; T.O. Plastics, Clearwater, $\mathrm{MN}$ ). Air temperature and light were as described above. Substrate was warmed to $21{ }^{\circ} \mathrm{C}$ with heat mats placed under trays. Cuttings were handmisted daily and irrigated to maintain moist substrate. After 1 week, cuttings were irrigated with tap water and fertilized once weekly as previously described.

After 4 weeks, rooted cuttings were transplanted into square plastic

Table 2. Stem elongation and branch number of Kalanchoe marnieviana, Kalanchoe rosei, and Kalanchoe streptantha 4 weeks after foliar sprays containing deionized water, ancymidol, benzyladenine, chlormequat chloride, daminozide, ethephon, paclobutrazol, or uniconazole were applied (Expt. 1).

\begin{tabular}{|c|c|c|c|c|c|c|c|}
\hline \multirow[b]{3}{*}{ Chemical } & \multirow[b]{3}{*}{$\begin{array}{l}\text { Concn } \\
(\mathrm{ppm})^{\mathrm{z}}\end{array}$} & \multicolumn{6}{|c|}{ Species } \\
\hline & & \multicolumn{2}{|c|}{ K. marnieriana } & \multicolumn{2}{|c|}{ K. rosei } & \multicolumn{2}{|c|}{ K. streptantba } \\
\hline & & $\begin{array}{c}\text { Stem } \\
\text { elongation } \\
(\mathrm{cm})^{\mathrm{z}}\end{array}$ & $\begin{array}{c}\text { Branches } \\
\text { (no.) }\end{array}$ & $\begin{array}{c}\text { Stem } \\
\text { elongation } \\
(\mathrm{cm})\end{array}$ & $\begin{array}{c}\text { Branches } \\
\text { (no.) }\end{array}$ & $\begin{array}{c}\text { Stem } \\
\text { elongation } \\
(\mathrm{cm})\end{array}$ & $\begin{array}{c}\text { Branches } \\
\text { (no.) }\end{array}$ \\
\hline Water & - & $7.8 \mathrm{ef}^{\mathrm{y}}$ & $1.2 \mathrm{ab}$ & $11.7 \mathrm{~b}-\mathrm{d}$ & $0.0 \mathrm{a}$ & $8.5 \mathrm{gh}$ & $0.0 \mathrm{a}$ \\
\hline Ancymidol & 15 & $7.6 \mathrm{~d}-\mathrm{f}$ & $0.9 \mathrm{ab}$ & $10.7 \mathrm{a}-\mathrm{d}$ & $0.0 \mathrm{a}$ & $6.5 \mathrm{~d}-\mathrm{g}$ & $0.0 \mathrm{a}$ \\
\hline Benzyladenine & 75 & $7.5 \mathrm{~d}-\mathrm{f}$ & $2.2 \mathrm{a}-\mathrm{c}$ & $11.6 \mathrm{~b}-\mathrm{d}$ & $0.0 \mathrm{a}$ & $5.0 \mathrm{~b}-\mathrm{d}$ & $0.0 \mathrm{a}$ \\
\hline Benzyladenine & 150 & 7.7 ef & $2.3 \mathrm{a}-\mathrm{c}$ & $11.1 \mathrm{a}-\mathrm{d}$ & $0.0 \mathrm{a}$ & $7.7 \mathrm{e}-\mathrm{h}$ & $0.0 \mathrm{a}$ \\
\hline Benzyladenine & 300 & $8.1 \mathrm{f}$ & $7.2 \mathrm{~d}$ & $12.5 \mathrm{~d}$ & $0.0 \mathrm{a}$ & $6.6 \mathrm{~d}-\mathrm{h}$ & $0.0 \mathrm{a}$ \\
\hline Chlormequat & 750 & $7.5 \mathrm{~d}-\mathrm{f}$ & $1.9 \mathrm{a}-\mathrm{c}$ & $11.9 \mathrm{~cd}$ & $0.0 \mathrm{a}$ & $6.1 \mathrm{c}-\mathrm{f}$ & $0.0 \mathrm{a}$ \\
\hline Chlormequat & 1500 & $6.5 \mathrm{c}-\mathrm{e}$ & $1.0 \mathrm{ab}$ & $11.6 \mathrm{~b}-\mathrm{d}$ & $0.0 \mathrm{a}$ & $4.7 \mathrm{~b}-\mathrm{d}$ & $0.0 \mathrm{a}$ \\
\hline Ethephon & 250 & 7.7 ef & $2.2 \mathrm{a}-\mathrm{c}$ & $10.2 \mathrm{a}-\mathrm{d}$ & $0.0 \mathrm{a}$ & $7.5 \mathrm{e}-\mathrm{h}$ & $0.0 \mathrm{a}$ \\
\hline Ethephon & 500 & $7.2 \mathrm{~d}-\mathrm{f}$ & $2.8 \mathrm{bc}$ & $9.5 \mathrm{a}-\mathrm{c}$ & $0.4 \mathrm{~b}$ & $7.2 \mathrm{e}-\mathrm{h}$ & $0.0 \mathrm{a}$ \\
\hline Ethephon & 1000 & $4.9 \mathrm{~b}$ & $3.5 \mathrm{c}$ & $9.2 \mathrm{ab}$ & $0.0 \mathrm{a}$ & $7.0 \mathrm{e}-\mathrm{h}$ & $0.0 \mathrm{a}$ \\
\hline Paclobutrazol & 10 & 7.7 ef & $1.9 \mathrm{a}-\mathrm{c}$ & $10.8 \mathrm{a}-\mathrm{d}$ & $0.0 \mathrm{a}$ & $6.4 \mathrm{~d}-\mathrm{f}$ & $0.0 \mathrm{a}$ \\
\hline Paclobutrazol & 20 & $6.8 c-f$ & $0.7 \mathrm{a}$ & $11.3 \mathrm{a}-\mathrm{d}$ & $0.0 \mathrm{a}$ & $5.8 \mathrm{c}-\mathrm{e}$ & $0.0 \mathrm{a}$ \\
\hline Paclobutrazol & 40 & $6.6 \mathrm{c}-\mathrm{f}$ & $1.4 \mathrm{ab}$ & $9.7 \mathrm{a}-\mathrm{c}$ & $0.0 \mathrm{a}$ & $6.5 \mathrm{~d}-\mathrm{g}$ & $0.0 \mathrm{a}$ \\
\hline Uniconazole & 5 & $6.9 \mathrm{~d}-\mathrm{f}$ & $1.6 \mathrm{a}-\mathrm{c}$ & $10.3 \mathrm{a}-\mathrm{d}$ & $0.0 \mathrm{a}$ & $5.8 \mathrm{c}-\mathrm{e}$ & $0.0 \mathrm{a}$ \\
\hline Uniconazole & 10 & $5.3 \mathrm{bc}$ & $1.8 \mathrm{a}-\mathrm{c}$ & $10.0 \mathrm{a}-\mathrm{d}$ & $0.0 \mathrm{a}$ & $3.0 \mathrm{ab}$ & $0.0 \mathrm{a}$ \\
\hline Uniconazole & 20 & $2.9 \mathrm{a}$ & $1.8 \mathrm{a}-\mathrm{c}$ & $8.7 \mathrm{a}$ & $0.0 \mathrm{a}$ & $1.3 \mathrm{a}$ & $0.0 \mathrm{a}$ \\
\hline
\end{tabular}

${ }^{{ }^{2}} 1 \mathrm{ppm}=1 \mathrm{mg} \cdot \mathrm{L}^{-1}, 1 \mathrm{~cm}=0.3937$ inch.

'Within-column means followed by different letters are significantly different by Tukey's honestly significant difference test at $P \leq 0.05$. 
Table 3. Stem elongation and branch number of Kalanchoe fedtschenkoi, Kalanchoe glaucescens, and Kalanchoe pumila 4 weeks after foliar sprays containing deionized water, ancymidol, benzyladenine, chlormequat chloride, daminozide, ethephon, paclobutrazol, or uniconazole were applied (Expt. 2).

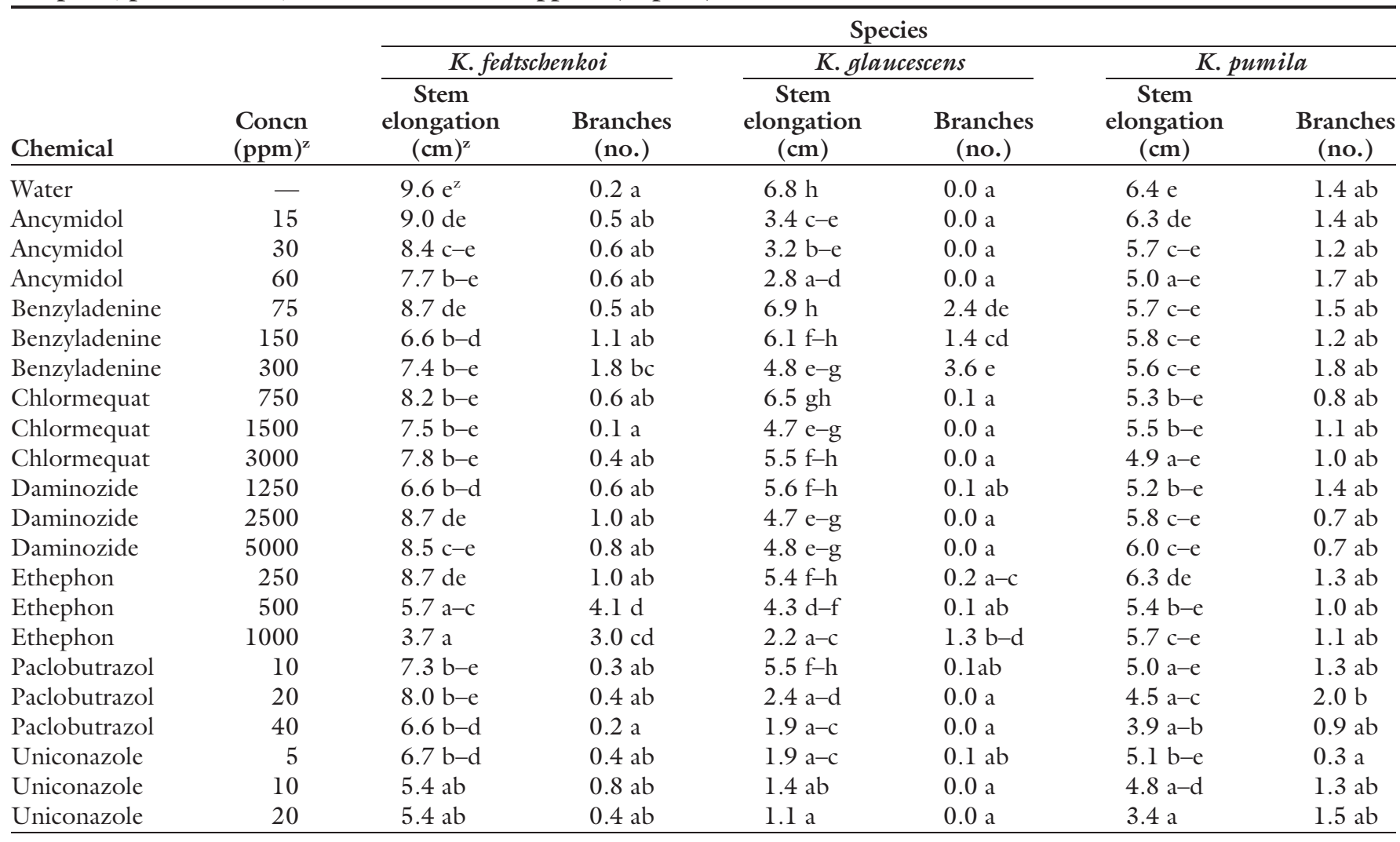

${ }^{2} \mathrm{l} \mathrm{ppm}=1 \mathrm{mg} \cdot \mathrm{L}^{-1}, \mathrm{l} \mathrm{cm}=0.3937$ inch

'Within-column means followed by different letters are significantly different by Tukey's honestly significant difference test at $P \leq 0.05$.

pots with 2.5 -inch sides $\left(15.3\right.$ inch $^{3}$ volume) filled with a high-porosity substrate (SB500). Pots were then placed back in the environment in which they were rooted without bottom heat or misting. Plants were irrigated with tap water and fertilized once weekly as previously described and were pinched to a single node 2 weeks after planting, resulting in two main shoots per plant.

Two weeks after pinching, five plants of each species were sprayed with: deionized water; 15,30 , or 60 ppm ancymidol (Abide; Fine Americas, Walnut Creek, CA); 75, 150, or $300 \mathrm{ppm}$ benzyladenine (Configure, Fine Americas); 750,1500 , or 3000 ppm chlormequat chloride (Citadel, Fine Americas); 1250, 2500, or 5000 ppm daminozide (Dazide 85 WSG, Fine Americas); 250, 500, or 1000 ppm ethephon (Florel; Southern Agricultural Insecticides, Palmetto, FL); 10,20 , or $40 \mathrm{ppm}$ paclobutrazol (Piccolo, Fine Americas); or 5, 10, or $20 \mathrm{ppm}$ uniconazole (Concise, Fine Americas). Concentrations of each a.i. were selected to span published recommended ranges commonly used for foliar applications in flowering potted plant production (Dole and Wilkins, 2005; Whipker et al., 2011). Solutions were applied to plants at a rate of $2 \mathrm{qt} / 100 \mathrm{ft}^{2}$ in a laboratory and allowed to dry for $4 \mathrm{~h}$ at $21^{\circ} \mathrm{C}$. Plants were then returned to the greenhouse environment previously described and grown for 4 weeks. Plants were irrigated with tap water as needed and fertilized weekly as previously described. The $P P F$ and air temperature at canopy height were measured, and environmental data are reported in Table 1.

Data were collected on the length of each shoot when PGRs were applied and 4 weeks after applications. Additionally, the number of branches $(>1 \mathrm{~cm})$ for each shoot was measured 4 weeks after PGR application. Stem elongation was calculated by subtracting shoot length when PGRs were applied from shoot length 4 weeks after PGR applications.

ExpTs. 2, 3, AND 4. Additional species were propagated, grown, and treated as described in Expt. 1 on 16
Jan. 2009 (K. glaucescens 'Freeling's Sensation', K. fedtschenkoi 'Aurora Borealis' and K. pumila; Expt. 2), 13 Mar. 2009 (K beauvardii, K. millotii, and $K$. Longiflora; Expt. 3), and 20 Mar. 0209 (K. manginii and K. rotundifolia; Expt. 4). Data were collected and calculated as described in Expt. 1. Experiments were conducted separately to accommodate the trialing of a wide range of PGRs at several concentrations on numerous species in available greenhouse space.

EXPERIMENTAL DESIGN AND STATISTICAL ANALYSES. The experiments were designed as a completely randomized design for each species. There were five replicates (individual plants) per species per treatment and two samples (shoots) per replicate. Analyses of variance and mean separation by Tukey's honestly significant difference test at $P \leq 0.05$ were performed using SPSS (version 17.0; IBM Corp., Armonk, NY).

\section{Results}

Expт. 1. Stem elongation of $K$. marnieriana treated with $3000 \mathrm{ppm}$ 
Table 4. Stem elongation and branch number of Kalanchoe beauvardii, Kalanchoe longiflora, and Kalanchoe milotii 4 weeks after foliar sprays containing deionized water, ancymidol, benzyladenine, chlormequat chloride, daminozide, ethephon, paclobutrazol, or uniconazole were applied (Expt. 3).

\begin{tabular}{|c|c|c|c|c|c|c|c|}
\hline \multirow[b]{3}{*}{ Chemical } & \multirow[b]{3}{*}{$\begin{array}{l}\text { Concn } \\
(\mathrm{ppm})^{\mathrm{z}}\end{array}$} & \multicolumn{6}{|c|}{ Species } \\
\hline & & \multicolumn{2}{|c|}{ K. beauvardii } & \multicolumn{2}{|c|}{ K. longiflora } & \multicolumn{2}{|c|}{ K. millotii } \\
\hline & & $\begin{array}{c}\text { Stem } \\
\text { elongation } \\
(\mathrm{cm})^{\mathrm{z}}\end{array}$ & $\begin{array}{c}\text { Branches } \\
\text { (no.) }\end{array}$ & $\begin{array}{c}\text { Stem } \\
\text { elongation } \\
(\mathrm{cm}) \\
\end{array}$ & $\begin{array}{c}\text { Branches } \\
\text { (no.) }\end{array}$ & $\begin{array}{c}\text { Stem } \\
\text { elongation } \\
(\mathrm{cm})\end{array}$ & $\begin{array}{c}\text { Branches } \\
\text { (no.) }\end{array}$ \\
\hline Water & - & $31.6 \mathrm{c}$ & $0.0 \mathrm{a}$ & $6.1 \mathrm{~h}$ & $0.1 \mathrm{a}$ & $5.1 \mathrm{~g}$ & $0.0 \mathrm{a}$ \\
\hline Ancymidol & 15 & $30.6 \mathrm{c}$ & $0.0 \mathrm{a}$ & $4.8 \mathrm{c}-\mathrm{h}$ & $0.2 \mathrm{a}$ & $3.7 \mathrm{f}$ & $0.1 \mathrm{a}$ \\
\hline Benzyladenine & 75 & $15.3 \mathrm{a}-\mathrm{c}$ & $0.0 \mathrm{a}$ & $5.2 \mathrm{~d}-\mathrm{h}$ & $0.9 \mathrm{a}$ & $3.3 \mathrm{c}-\mathrm{f}$ & $0.6 \mathrm{a}$ \\
\hline Benzyladenine & 150 & $25.0 \mathrm{a}-\mathrm{c}$ & $0.0 \mathrm{a}$ & $5.8 \mathrm{gh}$ & $0.1 \mathrm{a}$ & $3.6 \mathrm{f}$ & $0.6 \mathrm{a}$ \\
\hline Benzyladenine & 300 & $17.8 \mathrm{a}-\mathrm{c}$ & $0.0 \mathrm{a}$ & $4.4 \mathrm{~b}-\mathrm{f}$ & $1.0 \mathrm{a}$ & $2.9 \mathrm{a}-\mathrm{f}$ & $0.7 \mathrm{a}$ \\
\hline Chlormequat & 750 & $19.2 \mathrm{a}-\mathrm{c}$ & $0.0 \mathrm{a}$ & $5.4 \mathrm{e}-\mathrm{h}$ & $0.0 \mathrm{a}$ & $3.2 \mathrm{~b}-\mathrm{f}$ & $0.1 \mathrm{a}$ \\
\hline Chlormequat & 1500 & $15.4 \mathrm{a}-\mathrm{c}$ & $0.0 \mathrm{a}$ & $4.7 \mathrm{c}-\mathrm{f}$ & $0.4 \mathrm{a}$ & 3.4 ef & $0.0 \mathrm{a}$ \\
\hline Chlormequat & 3000 & $13.4 \mathrm{a}-\mathrm{c}$ & $0.0 \mathrm{a}$ & $4.4 \mathrm{c}-\mathrm{f}$ & $0.4 \mathrm{a}$ & $3.1 \mathrm{~b}-\mathrm{f}$ & $0.0 \mathrm{a}$ \\
\hline Ethephon & 250 & $19.9 \mathrm{a}-\mathrm{c}$ & $0.0 \mathrm{a}$ & $3.9 \mathrm{a}-\mathrm{d}$ & $0.6 \mathrm{a}$ & $3.4 \mathrm{~d}-\mathrm{f}$ & $0.4 \mathrm{a}$ \\
\hline Ethephon & 500 & $22.6 \mathrm{a}-\mathrm{c}$ & $0.0 \mathrm{a}$ & $4.1 \mathrm{a}-\mathrm{e}$ & $0.1 \mathrm{a}$ & $2.9 \mathrm{a}-\mathrm{f}$ & $0.2 \mathrm{a}$ \\
\hline Ethephon & 1000 & $13.6 \mathrm{a}-\mathrm{c}$ & $0.0 \mathrm{a}$ & $4.1 \mathrm{a}-\mathrm{d}$ & $0.7 \mathrm{a}$ & $2.8 \mathrm{a}-\mathrm{f}$ & $0.2 \mathrm{a}$ \\
\hline Paclobutrazol & 10 & $29.3 \mathrm{bc}$ & $0.0 \mathrm{a}$ & $4.8 \mathrm{c}-\mathrm{h}$ & $0.0 \mathrm{a}$ & $2.7 \mathrm{a}-\mathrm{f}$ & $0.0 \mathrm{a}$ \\
\hline Paclobutrazol & 20 & $20.6 \mathrm{a}-\mathrm{c}$ & $0.0 \mathrm{a}$ & $4.9 c-h$ & $0.3 \mathrm{a}$ & $3.1 \mathrm{~b}-\mathrm{f}$ & $0.0 \mathrm{a}$ \\
\hline Paclobutrazol & 40 & $19.6 \mathrm{a}-\mathrm{c}$ & $0.0 \mathrm{a}$ & $3.5 \mathrm{a}-\mathrm{c}$ & $0.2 \mathrm{a}$ & $2.3 \mathrm{ab}$ & $0.3 \mathrm{a}$ \\
\hline Uniconazole & 5 & $21.1 \mathrm{a}-\mathrm{c}$ & $0.0 \mathrm{a}$ & $4.3 \mathrm{~b}-\mathrm{f}$ & $0.7 \mathrm{a}$ & $2.7 \mathrm{a}-\mathrm{f}$ & $0.0 \mathrm{a}$ \\
\hline Uniconazole & 10 & $7.2 \mathrm{a}$ & $0.0 \mathrm{a}$ & $3.0 \mathrm{ab}$ & $0.6 \mathrm{a}$ & $2.3 \mathrm{a}-\mathrm{c}$ & $0.2 \mathrm{a}$ \\
\hline Uniconazole & 20 & $8.2 \mathrm{ab}$ & $0.0 \mathrm{a}$ & $2.9 \mathrm{a}$ & $0.3 \mathrm{a}$ & $2.0 \mathrm{a}$ & $0.1 \mathrm{a}$ \\
\hline
\end{tabular}

${ }^{\mathrm{z}} 1 \mathrm{ppm}=1 \mathrm{mg} \cdot \mathrm{L}^{-1}, 1 \mathrm{~cm}=0.3937$ inch.

'Within-column means followed by different letters are significantly different by Tukey's honestly significant difference test at $P \leq 0.05$.

chlormequat, $1000 \mathrm{ppm}$ ethephon, or $20 \mathrm{ppm}$ uniconazole were $1.7 \mathrm{~cm}$ (22\%), $2.9 \mathrm{~cm} \mathrm{(37 \% ),} \mathrm{or} 4.9 \mathrm{~cm}$ $(63 \%)$ less, respectively, than plants sprayed with water only (Table 2 ). While $40 \mathrm{ppm}$ paclobutrazol and 20 ppm uniconazole resulted in $K$. rosei with $2.0 \mathrm{~cm}(17 \%)$ or $3.0 \mathrm{~cm}(26 \%)$ less stem elongation than untreated plants, stem elongation of plants treated with 1000 ppm ethephon was $8.2 \mathrm{~cm}(70 \%)$ less. The highest concentrations of paclobutrazol and ancymidol suppressed stem elongation of $K$. streptantha by $2.0 \mathrm{~cm}(24 \%)$ to $2.5 \mathrm{~cm}(29 \%)$ compared with untreated plants, respectively; chlormequat chloride and uniconazole suppressed stem elongation by up to $4.3 \mathrm{~cm}(51 \%)$ to $7.2 \mathrm{~cm}$ $(85 \%)$. Benzyladenine (300 ppm) and ethephon (1000 ppm) increased branch number of $K$. marnieriana by 6.0 and 2.2 branches, respectively. Branch number of $K$. rosei and K. streptantha was unaffected by PGRs.

Expт. 2. The highest concentrations of ethephon, paclobutrazol, and uniconazole suppressed stem elongation of $K$. fedtschenkoi by $5.9 \mathrm{~cm}(61 \%)$,
$3.0 \mathrm{~cm} \mathrm{(31 \% ),} \mathrm{and} 4.2 \mathrm{~cm} \mathrm{(44 \% )}$ compared with untreated plants (Table 3 ). Stem elongation of $K$. glaucescens was controlled by every PGR, though ancymidol, ethephon, paclobutrazol, and uniconazole suppressed stem elongation more than chlormequat chloride and daminozide. Paclobutrazol and uniconazole were also the most effective in suppressing stem elongation of $K$. pumila by $2.5 \mathrm{~cm}(39 \%)$ and $3.0 \mathrm{~cm}(47 \%)$, respectively. Benzyladenine and ethephon increased branch number of $K$. fedtschenkoi up to 1.6 and 2.8 branches, respectively, and $K$. glaucescens by 3.6 and 1.3 branches, respectively, compared with untreated plants. No PGR affected branch number of $K$. pumila.

Expт. 3. Only foliar spray applications containing 10 or $20 \mathrm{ppm}$ uniconazole suppressed stem elongation of $K$. beauvardii compared with untreated plants (Table 4), though several PGRs including ancymidol, chlormequat chloride, ethephon, and paclobutrazol had a significant negative linear relationship between PGR concentration and stem elongation.
Alternatively, every PGR application controlled stem elongation of $K$. millotii compared with untreated plants. While foliar sprays containing any concentration of ancymidol did not affect stem elongation of $K$. longiflora, all other PGRs suppressed stem elongation. For instance, stem elongation of $K$. longiflora was suppressed by $1.7 \mathrm{~cm}(28 \%)$ and $5.4 \mathrm{~cm}(52 \%)$ for plants treated with $3000 \mathrm{ppm}$ chlormequat chloride and $20 \mathrm{ppm}$ uniconazole, respectively. Branch number of $K$. beawvardii and $K$. millotii were unaffected by PGRs, while branch number of $K$. longiflora increased by 0.9 when a foliar spray containing $300 \mathrm{ppm}$ benzyladenine was applied.

ЕхРт. 4. While applying 3000 ppm chlormequat chloride suppressed stem elongation of $K$. manginii and K. rotundifolia by $2.7 \mathrm{~cm}(44 \%)$ and $1.9 \mathrm{~cm}(26 \%)$, respectively (Table 5 ), paclobutrazol suppressed stem elongation by $3.3 \mathrm{~cm}(53 \%)$ and $4.5 \mathrm{~cm}$ (62\%) for K. manginii and K. rotundifolia, respectively. Daminozide had no effect on stem elongation of either species. While applying $\geq 500 \mathrm{ppm}$ 
Table 5. Stem elongation and branch number of Kalanchoe manginii and Kalanchoe rotundifolia 4 weeks after foliar sprays containing deionized water, ancymidol, benzyladenine, chlormequat chloride, daminozide, ethephon, paclobutrazol, or uniconazole were applied (Expt. 4).

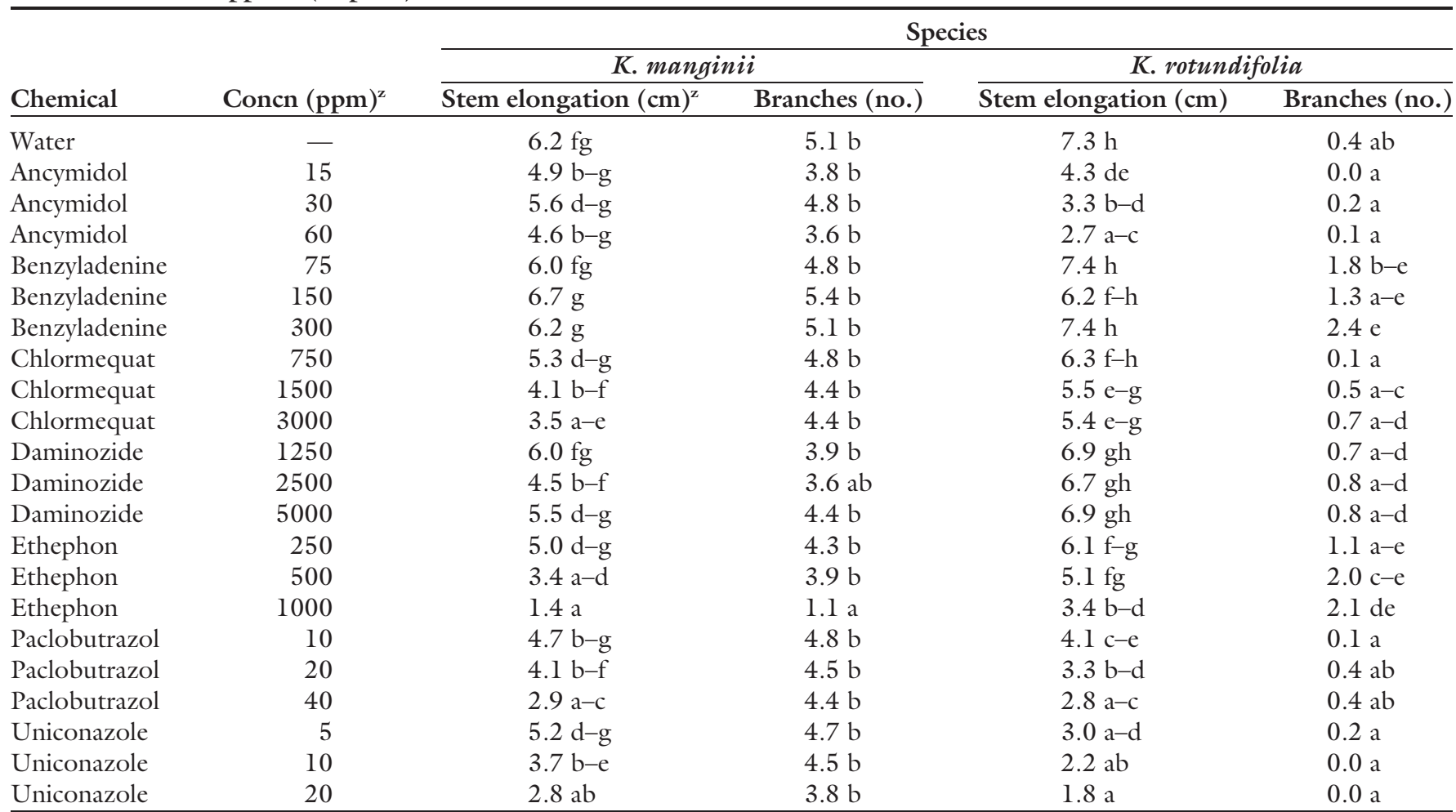

${ }^{2} 1 \mathrm{ppm}=1 \mathrm{mg} \cdot \mathrm{L}^{-1}, \mathrm{l} \mathrm{cm}=0.3937$ inch.

${ }^{y}$ Within-column means followed by different letters are significantly different by Tukey's honestly significant difference test at $P \leq 0.05$.

ethephon or $300 \mathrm{ppm}$ benzyladenine increased branch number of $K$. rotundifolia by about two branches, stem elongation and branch number of $K$. manginii decreased with ethephon application. Applying benzyladenine had no effect on stem elongation or branching of $K$. manginii.

\section{Discussion}

The efficacy of PGR applications in controlling stem elongation varied with species (Tables $2-5$ ). Similar variation in efficacy of PGRs for plant height suppression was reported for kalanchoe, primarily among $K$. blossfeldiana cultivars (Adriansen, 1989; Carlson et al., 1977; Cathey and Stuart, 1961; Hwang et al., 2008; Lee et al., 2003; Nightingale, 1970; Pertuit, 1973; Ueber, 1998; Zimmer, 1985). In general, paclobutrazol and uniconazole appeared to be the most efficacious a.i. among PGRs for suppressing stem elongation across kalanchoe species in this study (Tables 2-5). There were several cases where stem elongation was less for several PGRs as concentration increased, though there were not significant differences when compared with untreated plants (Tables
2-5). This may indicate that PGR concentrations above the range used in this study may warrant evaluation. Or, as in the case for the narrow-leaved and vining $K$. beauvardii achieving uniform coverage from foliar sprays may be challenging, thus contributing to variation in application coverage and subsequent plant response.

The highest concentrations of PGRs such as chlormequat chloride and daminozide did not significantly suppress stem elongation compared with untreated plants for some species (Tables 2-5). However, most concentrations of paclobutrazol and uniconazole significantly suppressed stem elongation for many species in this study (Tables $2-5$ ). While chlormequat chloride and daminozide are absorbed primarily by leaves, paclobutrazol and uniconazole are absorbed primarily by the stems and roots (Barrett, 2001). The broad efficacy in suppressing stem elongation across species by paclobutrazol and uniconazole may be attributed to PGR solution being applied to the substrate surface during foliar applications and subsequent root uptake. Alternatively, perhaps the stem is more effective at absorption of PGRs. The epidermal layer of stems and leaves of plants from arid areas is covered with a thick cuticle to minimize water loss (Beck, 2010). Many kalanchoe are native to arid areas and have a thick, waxy cuticle (Rauh, 1995), which in turn may reduce the efficacy of foliar PGR applications. Therefore, substrate drenches may be an application method with promise for some taxa.

Branching of several kalanchoe species was affected by benzyladenine and ethephon (Tables 2-5). Although Pertuit (1973) reported that foliar sprays containing dikegulac sodium and ethephon increased branch number of $K$. blossfeldiana, many modern $K$. blossfeldiana cultivars are free-branching as a result of targeted breeding and selection for that trait (Mikkelsen, 1987). However, many of the species in this study are not (Currey and Erwin, 2011a). Therefore, the ability to increase branching using foliar PGR applications as opposed to mechanically (i.e., pinching) is a cost-effective method to improve the ornamental quality of germplasm.

Phytotoxicity was observed only when ethephon was applied to $K$. 
manginii (Table 5). When ethephon concentration increased to $1000 \mathrm{ppm}$, the apical meristem was distorted, resulting in stunted plants with few unfolded leaves and branches. While not phytotoxic per se, severe stunting was observed when uniconazole was applied to $K$. glaucescens (Table 3 ) and $K$. rotundifolia (Table 5 ). At 5 and $10 \mathrm{ppm}$ uniconazole, $K$. glaucescens stems were highly compressed, and as concentrations increased to 20 ppm, both $K$.glaucescens and $K$. rotundifolia were very stunted.

The efficacy of PGRs in controlling stem elongation is related to plant growth which, in turn, is influenced by cultural practices and the greenhouse environment (Blanchard and Runkle, 2011; Faust, 2011; Warner and Erwin, 2001; Whipker et al., 2011). For example, stem elongation may increase under a positive DIF and low-light conditions. Alternatively, higher daily light integral (DLI) and average daily temperatures (ADT) can increase growth potential. Therefore, when stem elongation or growth potential increases because of environmental conditions, PGR efficacy may be reduced and vice versa. In our experiments, the DIF was $\approx 4{ }^{\circ} \mathrm{C}$ for all four experiments (Table 1). However, the ADT and DLI increased with each experiment (Table l). While we believe our results provide a basis to select a.i. and concentrations appropriate for suppressing stem elongation of the kalanchoe species studied in this experiment, different environmental conditions may elicit a slightly different response to PGRs.

\section{Conclusions}

Our data indicate that stem elongation of the 11 kalanchoe species in this study may be controlled with foliar application of commonly available PGRs. Furthermore, branching of several species may also be enhanced using PGR sprays. While we have identified effective chemicals here, we encourage producers to conduct trials to determine appropriate concentrations required for their unique production scenarios, locations, and facilities. Additionally, the concentration of PGRs required for successful height control and branching will depend on the desired plant height and form.

\section{Literature cited}

Andersen, A.S. and L. Andersen. 2000. Growth regulation as a necessary prerequisite for introduction of new plants. Acta Hort. 541:183-192.

Adriansen, E. 1989. Growth and flowering in pot plants soaked with plant growth regulator solutions in ebb and flood benches. Acta Hort. 251:319-328.

Barrett, J. 2001. Mechanisms of action, p. 32-41. In: M.L. Gaston, P.S. Konjoian, L.A. Kunkle, and M.F. Wilt (eds.). Tips on regulating growth of floriculture crops. OFA Services, Inc., Columbus, $\mathrm{OH}$.

Beck, C.B. 2010. An introduction to plant structure and development: Plant anatomy for the twenty-first century. Cambridge University Press, Cambridge, UK.

Blanchard, M.G. and E.S. Runkle. 2007. Dipping bedding plant liners in paclobutrazol or uniconazole inhibits subsequent stem extension. HortTechnology 17:178182.

Blanchard, M.G. and E.S. Runkle. 2011. Temperature, p. 67-81. In: J. Nau (ed.). Ball redbook. 18th ed. Ball Publishing, West Chicago, IL.

Boldt, J.K. 2008. Cultural and environmental factors influence the performance of Angelonia angustifolia cultivars. Univ. of Florida, Gainesville, MS Thesis.

Carlson, W.H., S. Schnabel, J. Schnabel, and C. Turner. 1977. Concentration and application time of ancymidol for growth retardation of Kalanchoe blossfeldiana Poellniz. cv. Mace. HortScience 12:568.

Cathey, H.M. and N.W. Stuart. 1961. Comparative plant growth-retarding activity of AMO-1618, phosfon, and CCC. Bot. Gaz. 123:51-57.

Currey, C.J. 2009. Factors affecting flowering and growth in the genus Kalanchoe. Univ. of Minnesota, St. Paul, MS Thesis.

Currey, C.J. and J.E. Erwin. 2010. Variation among Kalanchoe species in their flowering response to photoperiod and short-day cycle number. J. Hort. Sci. Biotechnol. 85:350-354.

Currey, C.J. and J.E. Erwin. 2011a. Photoperiodic flower induction of several Kalanchoe species and ornamental qualities of the flowering species. HortScience 46:35-39.

Currey, C.J. and J.E. Erwin. 2011b. Photosynthetic daily light integral impacts growth and flowering of several kalanchoe species. HortTechnology 21:98-102.

Currey, C.J. and R.G. Lopez. 2010. Paclobutrazol pre-plant bulb dips effectively control height of 'Nellie White' easter lily. HortTechnology 20:357-360.

Currey, C.J. and R.G. Lopez. 2011. Early flurprimidol applications suppress final height of four poinsettia cultvars. HortTechnology 21:35-40.

Davis, T.D. and A. Andersen. 1989. Growth retardants as aids in adapting new floriculture crops to pot culture. Acta Hort. 252:77-86.

Descoings, B. 2005. Kalanchoe, p. 143 181. In: E. Eggli (ed.). Illustrated handbook of succulent plants: Crassulaceae. Springer, Berlin, Germany.

Dole, J.M. and H.F. Wilkins. 2005. Floriculture: Principles and species. 2nd ed. Prentice Hall, Upper Saddle River, NJ.

Faust, J.E. 2011. Light, p. 83-94. In: J. Nau (ed.). Ball redbook. 18th ed. Ball Publishing, West Chicago, IL.

Gent, M.P.N. and R.J. McAvoy. 2000. Plant growth retardants in ornamental horticulture, p. 89-146. In: A.S. Basara (ed.). Plant growth regulators in agriculture and horticulture: Their role and commercial uses. Food Products Press, Binghamton, NY.

Gibson, J.L. and B.E. Whipker. 2001. Ornamental cabbage and kale cultivar comparison study: Growth characteristics and response to daminozide and uniconazole foliar sprays. HortTechnology 11:376-380.

Gibson, J.L. and B.E. Whipker. 2003. Efficacy of plant growth regulators on the growth of vigorous Osteospermum cultivars. HortTechnology 13:132135.

Hwang, S.J., M.Y. Lee, I. Sivanesan, and B.R. Jeong. 2008. Growth control of kalanchoe cultivars Rako and Goldstrike by application of paclobutrazol and uniconazole as soaking treatment of cuttings. Afr. J. Biotechnol. 7:4212-4218.

Krug, B.A., B.E. Whipker, I. McCall, and J.M. Dole. 2005. Comparison of flurprimidol to ethephon, paclobutrazol, and uniconazole for hyacinth height control. HortTechnology 15:872-874.

Krug, B.A., B.E. Whipker, I. McCall, and J.M. Dole. 2007. Tulip cultivar variations with flurprimidol. J. Appl. Hort. 9:66-68.

Lee, M.Y., N.H. Choi, and B.R. Jeong. 2003. Growth and flowering of kalanchoe 'Rako' as affected by concentration of paclobutrazol and uniconazole. Acta Hort. 624:287-296.

Lyons, R.E. and C.L. Hale. 1987. Comparison of pinching methods on selected species of Columnea, Kalanchoe and Crassula. HortScience 22:72-74. 
Mikkelsen, J.C. 1987. Commercial aspect of new crop development. Acta Hort. 205:49-56.

Nightingale, A.E. 1970. The influence of succinamic acid 2,2-dimethylhydrazide on the growth and flowering of pinched vs unpinched plants of the kalanchoe hybrid 'Mace'. J. Amer. Soc. Hort. Sci. 95:273-276.

Nordwig, G.J. 1999. Evaluation of floral inductive requirements and commercial potential of Asclepias species. Univ. of Minnesota, St. Paul, MS Thesis.

Pertuit, A.J. 1973. The effects of terminal pinching and chemical growth regulation of Kalanchoe blossfeldiana v. Poellnitz. Univ. Georgia Res. Bul. 132:3-14.

Rademacher, W. 2000. Growth retardants: Effects on gibberellin biosynthesis and other metabolic pathways. Annu. Rev. Plant Physiol. Plant Mol. Biol. 51:501-531.

Rauh, W. 1995. Succulent and xerophytic plants of Madagascar, Vol. II. Strawberry Press, Mill Valley, CA.
Roh, M.S. and R.H. Lawson. 1998. Requirements for new floral crops- Perspectives for the United States of America. Acta Hort. 454:29-38.

Schnelle, R.A. and J.E. Barrett. 2010. Paclobutrazol concentration and substrate moisture status impact efficacy of liner dips for size control of three bedding plants. HortTechnology 20:735-739.

Seely, J.G. 1979. Interpretation of growth regulator research with floriculture crops. Acta Hort. 91:83-92.

Sellmer, J.C., C.R. Adkins, I. McCall, and B.E. Whipker. 2001. Pampas grass responses to ancymidol, paclobutrazol, and uniconazole substrate drenches. HortTechnology 11:216-219.

Srivastava, L.M. 2002. Plant growth and development: Hormones and environment. Academic Press, San Diego, CA.

Ueber, E. 1998. Hemmstoffe bei Kalanchoe: Topflor wirkt im gut. TaspoGartenbaumagazin 7:12-14.
Warner, R.M. and J.E. Erwin. 2001. Temperature. p. 10-17. In: M.L. Gaston, P.S. Konjoian, L.A. Kunkle, and M.F. Wilt (eds.). Tips on regulating growth of floriculture crops. OFA Services, Inc., Columbus, $\mathrm{OH}$

Warner, R.M. and J.E. Erwin. 2003. Effect of plant growth retardants on stem elongation of hibiscus species. HortTechnology 13:293-296.

Whipker, B.E. and S. Dasoju. 1998. Potted sunflower growth and flowering responses to foliar applications of daminozide, paclobutrazol, and uniconazole. Hort Technology 8:86-88.

Whipker, B.E., I. McCall, and J. Latimer. 2011. Growth regulators, p. 95-105. In: J. Nau (ed.). Ball redbook. 18th ed. Ball Publishing, West Chicago, IL.

Zimmer, K. 1985. Kalanchoe porphyrocalyx, p. 236-239. In: A.H. Halevy (ed.). Handbook of flowering, Vol. III. CRC Press, Boca Raton, FL. 